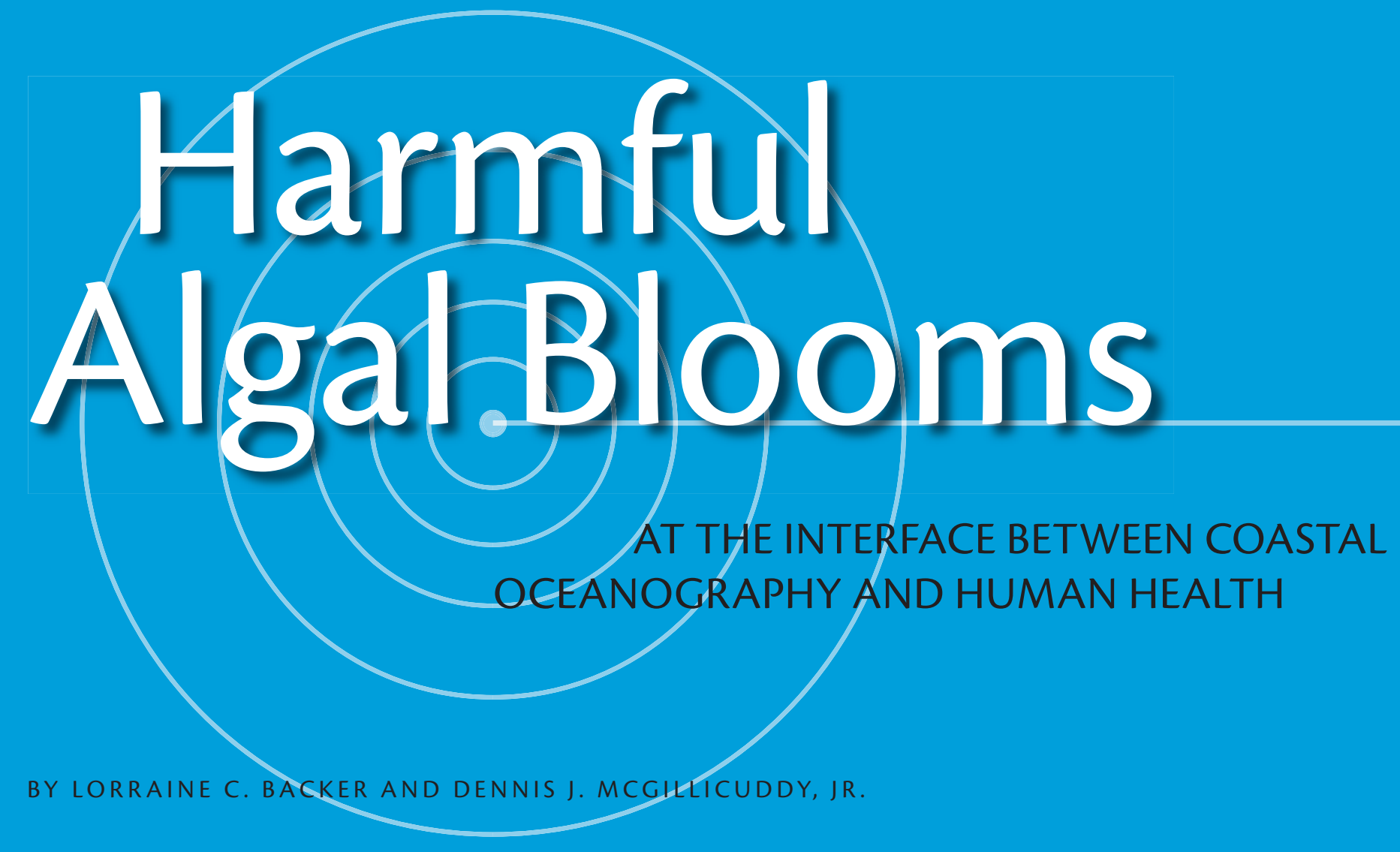

Algal blooms are a common occurrence in aquatic environments. A subset of these blooms poses environmental or public-health threats, and it is therefore referred to as "harmful algal blooms," or HABs. Some HABs are harmful by virtue of their sheer biomass, whereas others are associated with algal blooms capable of producing toxins. During a HAB event, algal toxins can accumulate in predators and organisms higher up the food web. Toxins may also be present in ambient waters, where wave action or human activities can create aerosols containing toxins and cellular debris. Animals, including humans, can thus be exposed to HAB-related toxins when they eat contaminated seafood, have contact with contaminated water, or inhale contaminated aerosols.

We have known for decades about many of the illnesses associated with marine HABs. We know that the toxins causing these illnesses are very stable molecules and are not destroyed by any method of food preservation or preparation. However, many unanswered questions remain about diagnosis, treatment, chronic effects, and other clinical and epidemiologic characteristics of these illnesses. Given that HAB events are becoming more frequent in the world's waters (Glibert et al., 2005), a pressing need exists to understand, predict, and eventually mitigate the public-health effects from these blooms.

The nature of a HAB event, including physical bloom characteristics and its ultimate effects on public health and the environment, is inextricably related to coastal oceanography. Many algal blooms originate well offshore, with the ambient physical, chemical, and biological environments playing a major role in bloom evolution. As such, the threat to human health is a nearshore manifestation of regional-scale plankton dynamics. In other cases, anthropogenic, point-source pollution is responsible for triggering both the bloom and the subsequent adverse effects. Regardless of whether the problem begins offshore as part of a natural cycle or a nearshore environmental disturbance, HAB effects are ultimately regulated by hydrodynamic transport of the harmful organisms into and out of coastal areas that constitute the conduit for human exposure to the organisms and their associated toxins. 


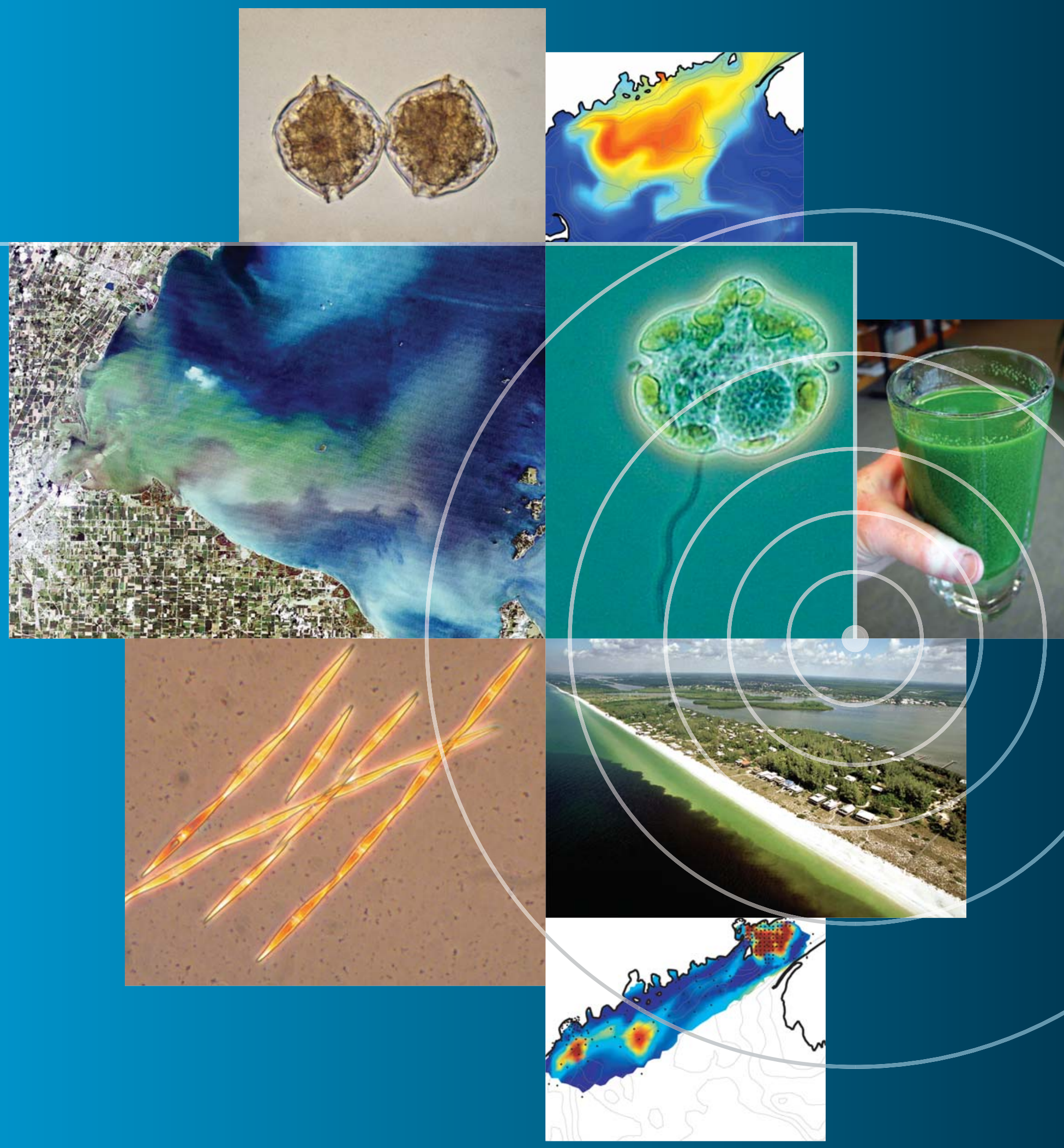




\section{HABS AND HUMAN HEALTH}

Probably the best-known human health effects caused by HAB-related organisms are the shellfish poisonings: amnesic, azaspiracid, diarrhetic, neurotoxic, and paralytic shellfish poisoning. A specific illness associated with eating contaminated fish is ciguatera fish poisoning, and another group of illnesses may be associated with water exposure to the cyanobacteria or blue green algae. The

Lorraine C. Backer (Ifb9@ocdc.gov) is Team Leader, Emerging Environmental Threats Team, National Center for Environmental Health, Centers for Disease Control and Prevention, Chamblee, GA, USA. Dennis

\section{J. McGillicuddy, Jr. is Deputy Director,}

Woods Hole Center for Oceans and Human Health, and Associate Scientist, Department of Applied Ocean Physics and Engineering, Woods Hole Oceanographic Institution, Woods Hole, MA, USA. following provides brief descriptions of some key HAB-related health effects, the culprit organisms, their toxins, and some illustrative oceanographic examples (see reviews by Fleming et al., 2002; Backer et al., 2003; and Backer et al., 2005b).

\section{Amnesic Shellfish Poisoning}

In 1987, a new type of human illness, termed amnesic shellfish poisoning (ASP), was diagnosed in people who had eaten mussels from Prince Edward Island (Perl et al., 1990). ASP is caused by domoic acid, which can act as an excitatory neurotransmitter. The source of the domoic acid in this 1987 outbreak was apparently a diatom, Pseudonitzschia multiseries (= Nitzschia pungens) (Figure 1), found in the coastal areas where mussels were cultivated. ASP victims reported gastrointestinal symptoms (e.g., vomiting, abdominal cramps, diarrhea) and neurologic symptoms

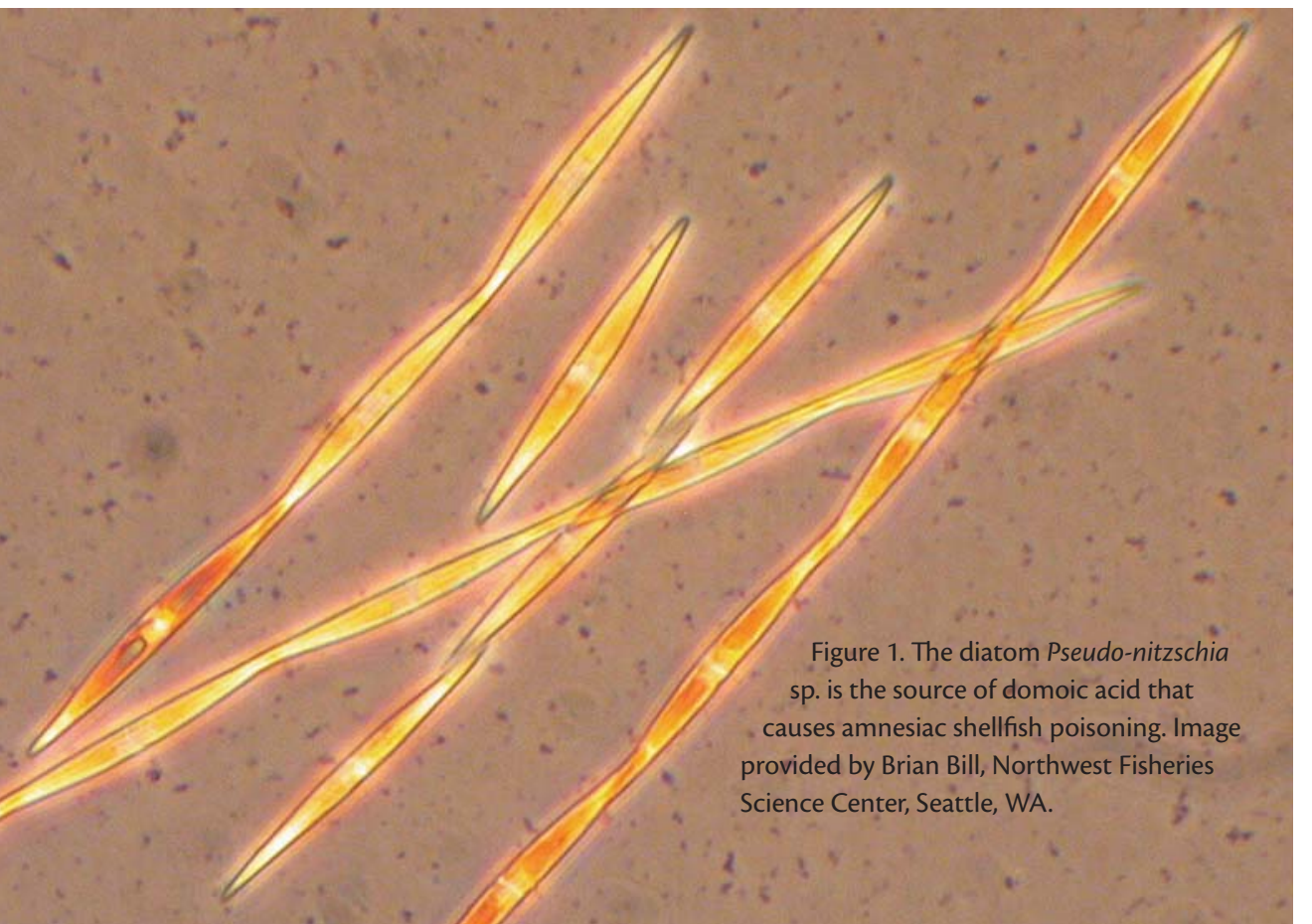

(e.g., incapacitating headache and shortterm memory loss) (Perl et al., 1990).

ASP outbreaks along the Pacific coast between Washington state and British Columbia appear to be primarily modulated by the activity of an eddy that typically resides offshore of the Straits of Juan de Fuca (Figure 2; also see results from the Ecology and Oceanography of Harmful Algal Blooms-Pacific Northwest program at http://www.ecohabpnw.org). The nutrient supply to this eddy is quasisteady, leading to enhanced biomass (including Pseudo-nitzschia in varying numbers) in this region, particularly on the perimeter of the eddy (MacFadyen et al., in preparation). Surface currents can transport materials from the eddy to adjacent shelf waters (MacFadyen et al., 2005), providing a direct pathway for intoxication of coastal razor clam populations, and creating a periodic public-health risk for people harvesting the clams.

The Olympic Region Harmful Algal Blooms partnership (Trainer and Suddleson, 2005; see http://www.orhab. org/) monitors seawater at several coastal sites for a rapid increase in the numbers of Pseudo-nitzschia and for the toxins that may originate from the Juan de Fuca eddy. The combination of microscopic monitoring of algae and the assessment of cellular toxicity using commercially available test strips gives resource managers an early warning of dangerous levels of toxins in razor clams.

\section{Diarrhetic Shellfish Poisoning}

The first cases of human illness from eating mussels contaminated with algal toxins occurred in the 1970s in the Netherlands (Kat, 1979) and Japan (Yasumoto 
AVHRR (18 July 1997)

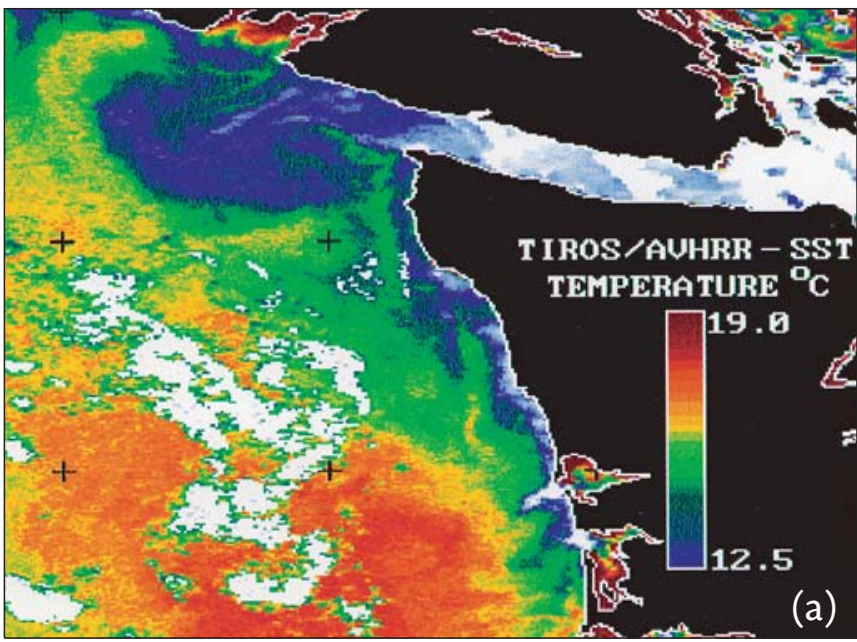

Figure 2. Satellite-derived sea surface temperature (SST), particulate domoic acid ( $\mu \mathrm{g} / \mathrm{L})$ and total Pseudo-nitzschia cell numbers $\left(10^{6}\right.$ cells/L) in surface seawater July 1997 (modified from Trainer et al., 2002). Spatial patterns show a coincidence of colder temperature (dark blue in upper panel), higher domoic acid, and greater numbers of Pseudo-nitzschia cells offshore of the Juan de Fuca Strait. The colder offshore water is indicative of the Juan de Fuca eddy. Colder water along the Washington coast is indicative of local wind-driven upwelling. Source: http://www.ecohabpnw. org/overview.html.
Domoic acid (7-19 July 1997)

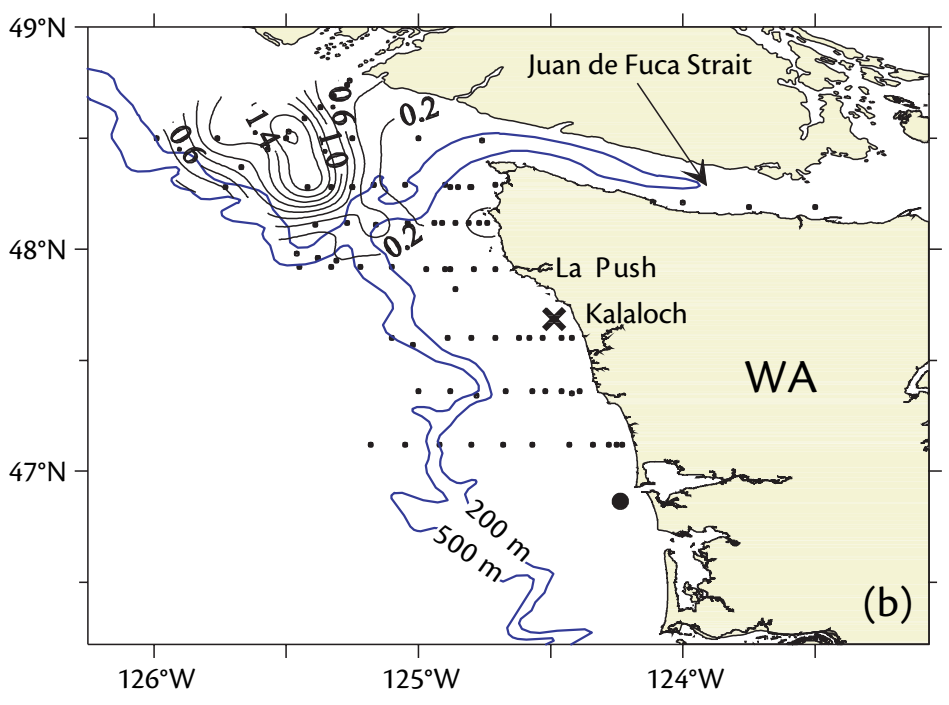

Pseudo-nitzschia cells (7-19 July 1997)

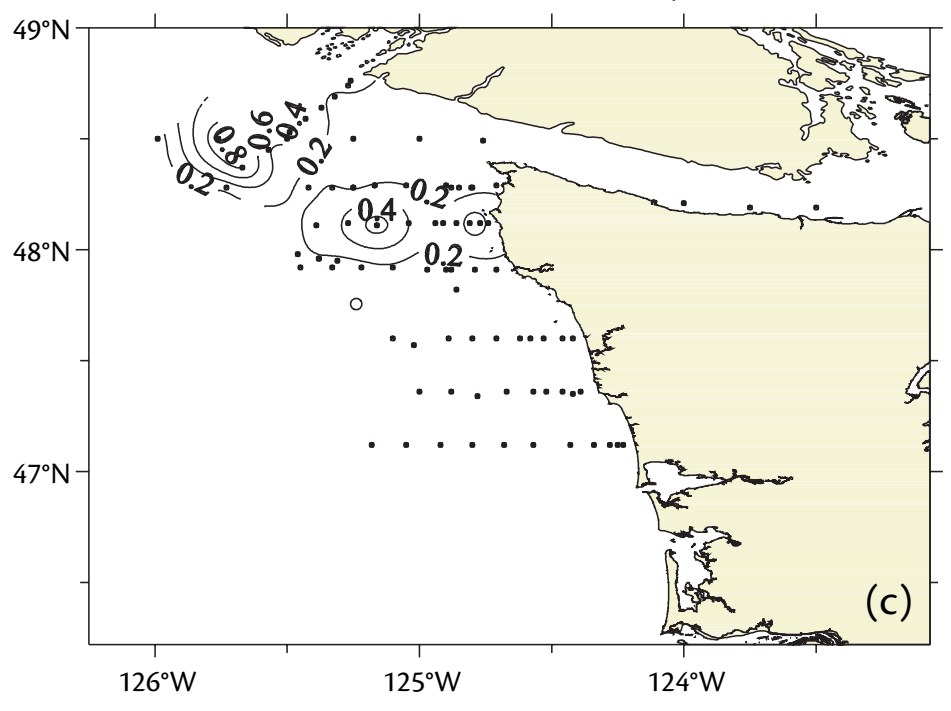

et al., 1978). The toxin syndrome, called diarrhetic shellfish poisoning (DSP), is found primarily in Europe, Japan, and parts of South America. Outbreaks can involve hundreds of people (Aune and Yndestad, 1993).

The toxins associated with DSP, including okadaic acid and several congeners of dinophysistoxins (DTX), are produced by dinoflagellates (e.g., Dinophysis spp. or Prorocentrum spp.). Mussels and scallops feeding on these microalgae accumulate the toxins (Aune and Yndestad, 1993). DSP produces severe gastrointestinal (e.g., diarrhea, nausea, vomiting, abdominal pain) symptoms within 30 minutes to 3 hours of eating contaminated shellfish. Victims reportedly recover within a few days (Yasumoto et al., 1978; Kat, 1979).

Algae of the genus Dinophysis typically inhabit the transition region between coastal and offshore waters (Smayda and Reynolds, 2001) and are therefore subject to a wide variety of physical-oceanographic forcing mechanisms. These dinoflagellates are often found in thin subsurface layers confined to the pycnocline (Gentien et al., 2005). Studies along the Iberian coast have revealed intricate relationships between D. acuta populations and wind-driven coastal upwelling phenomena (Reguera et al., 1995). Peak 
concentrations of $D$. acuta generally occur in the subsurface stratified waters of the pycnocline in association with relaxation of a prior upwelling event, or even during downwelling conditions. These blooms are thought to result from in situ growth and physical aggregation that takes place when upward-swimming organisms encounter regions of convergence (e.g., Franks, 1997).

\section{Neurotoxic Shellfish Poisoning and Respiratory Irritation}

Neurotoxic shellfish poisoning (NSP) has been reported along the Gulf Coast in the southeastern United States and eastern Mexico since the 1890s (Steidinger, 1993) and NSP-like symptoms have been reported by people eating shellfish from New Zealand (Ishida et al., 1996). Outbreaks of NSP have involved toxic oysters, clams, and other suspensionfeeders that accumulate toxins during red tide $\mathrm{HAB}$ events.

The toxins associated with NSP are polyether compounds called brevetoxins (Baden, 1989; Schulman et al., 1990) produced by the dinoflagellate Gymnodinium breve (formerly Ptychodiscus brevis and recently renamed Karenia brevis [Daugbjerg et al., 2000]) (Figure 3). The acute symptoms of NSP are similar to those reported with ciguatera fish poisoning, and include abdominal pain, nausea, diarrhea, burning pain in the rectum, headache, bradycardia, and dilated pupils. NSP victims have also reported temperature sensation reversals, myalgia, vertigo, and ataxia (McFarren et al., 1965; Hughes and Merson, 1976; Baden, 1983; Sakamoto et al., 1987).

In addition to NSP, brevetoxins can cause respiratory distress and eye irritation when individuals inhale sea spray contaminated with these toxins (Music et al., 1973). Recent studies have found that healthy lifeguards periodically exposed to aerosolized brevetoxins during Florida red tide events experience acute respiratory symptoms, but do not appear to have chronic effects (Backer et al., 2005a). In addition, people with asthma show not only acute respiratory symptoms, but also small changes in lung function immediately after they spend even short periods of time on the beach during Florida red tides when onshore

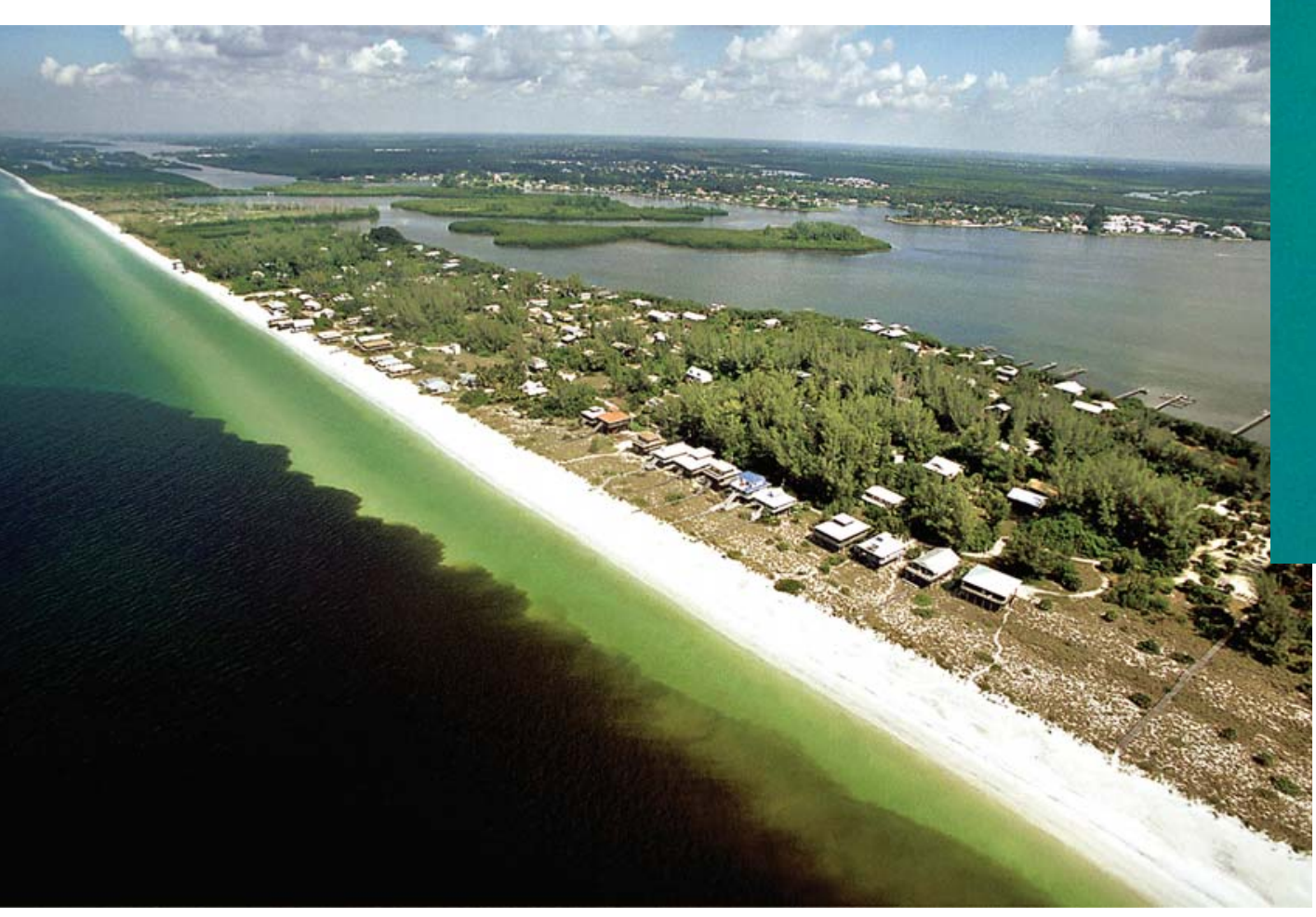

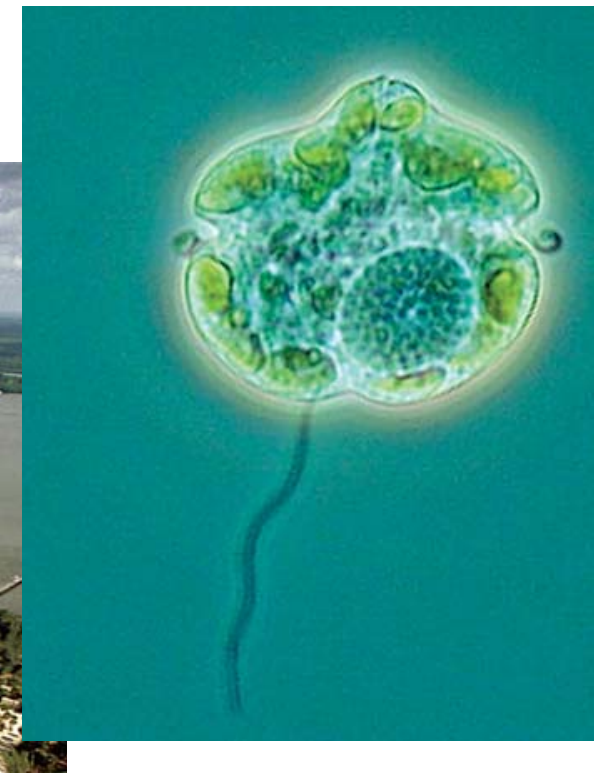

Figure 3. Above: the dinoflagellate Karenia Brevis, the causative organism of red tides on the West Florida shelf (image by David Patterson, Marine Biological Laboratory, Woods Hole, MA, and provided by micro*scope (http://microscope.mbl. edu). Left: Aerial view of a K. brevis bloom along a Florida beach (photo by Paul Schmidt, Charlotte Sun). 
winds cause aerosol exposures (Fleming et al., 2005) (see case study by Abraham and Baden, this issue).

Blooms of $K$. brevis on the west Florida shelf typically originate in offshore waters, $20 \mathrm{~km}-70 \mathrm{~km}$ from the coast (Steidinger and Haddad, 1981). The organism can form extraordinarily dense blooms, clearly visible to the naked eye (Figure 3, lower panel) and to satellitebased ocean color sensors (Figure 4). Although the underlying ecologic dynamics of these blooms and the ultimate source of nutrients needed to produce such biomass are still under debate (Walsh and Steidinger, 2001; Walsh et al., 2003), their visibility from space has led to satellite-based methods for monitoring and prediction (Stumpf et al., 2003).
The Gulf of Mexico HAB Bulletin uses satellite imagery, field observations, and buoy data to provide information on the location, extent, and potential for development or movement of $K$. brevis blooms (http://www.csc.noaa.gov/crs/ habf). Satellite imagery is used to identify areas that have undergone rapid changes in chlorophyll concentrations, usually due to high growth, aggregation, or resuspension.

Because such temporal changes can also be caused by blooms of non-toxic phytoplankton species, suspected areas of $K$. brevis red tide must be confirmed with in situ measurements. Following this confirmation, short-term predictions of bloom transport and landfall can be computed using meteorologic forecasts to compute estimates of winddriven surface currents. The NOAA "HAB Bulletin" (http://coastwatch.noaa. gov/hab/bulletins_ms.htm) and the Florida Fish and Wildlife Research Institute Bulletin (http://research.myfwc.com/) include up-to-date analyses of the current situation, predictions, and supporting data to help managers decide where to obtain their next samples and how to prepare for these blooms.

\section{Paralytic Shellfish Poisoning}

Paralytic shellfish poisoning (PSP) has been known in the Pacific Northwest of the United States for centuries (Kao, 1993). Human poisonings have been recorded primarily in North America (Prakash et al., 1971), Europe and Asia,

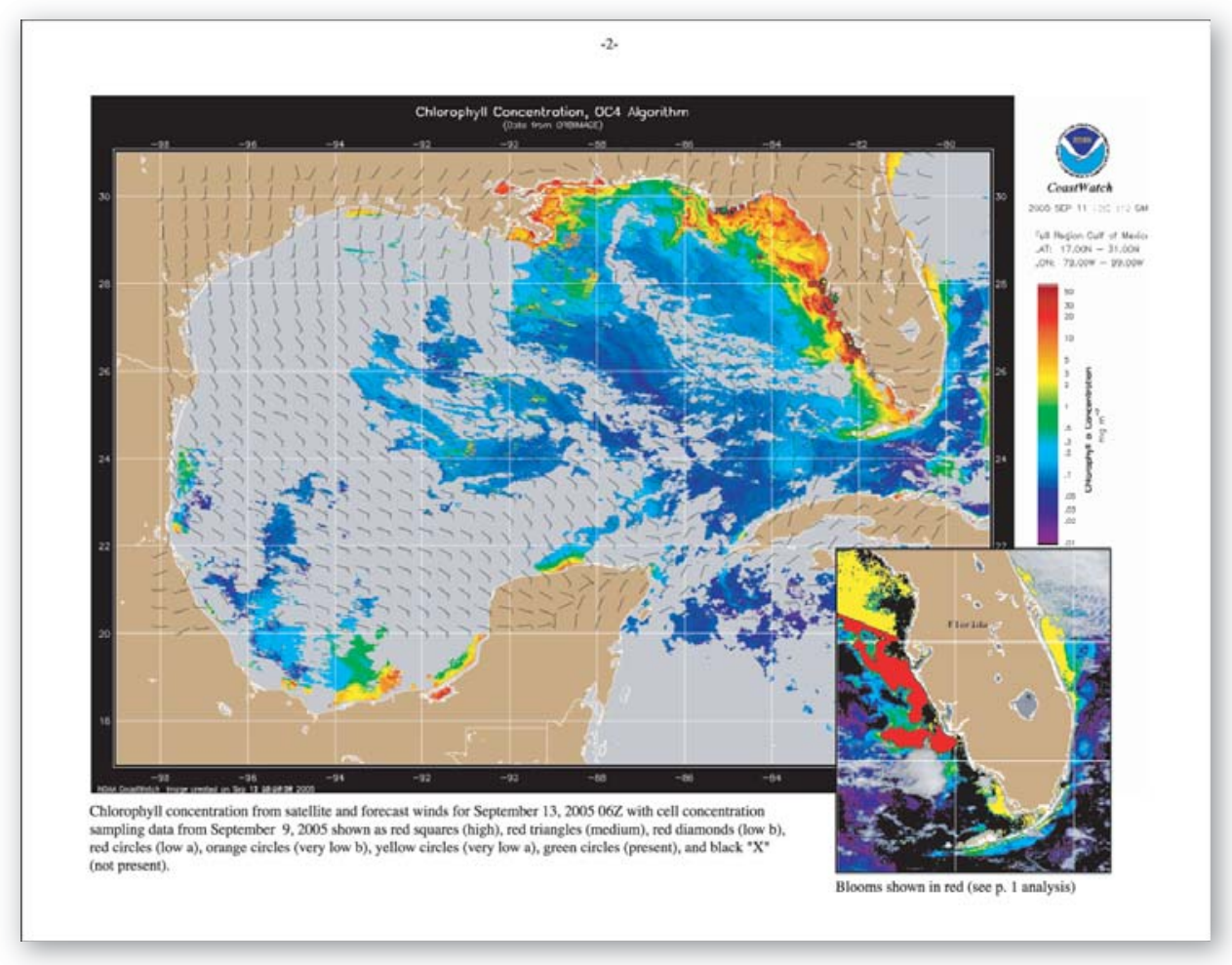

Figure 4. Sample image, from NOAA's Gulf of Mexico HAB bulletin, illustrating identification and tracking of $K$. brevis blooms using ocean color imagery (see http://www.csc. noaa.gov/crs/habf/). The accompanying "Conditions Report" reads: "A harmful algal bloom has been identified from northern Pinellas to northern Collier County. Moderate to high impacts are possible through Wednesday, with moderate impacts Thursday. A harmful algal bloom has been identified in Franklin, Taylor, and Dixie Counties. Very low to low impacts are possible in Franklin County through Thursday, and moderate impacts are possible in Taylor and Dixie Counties." 
but outbreaks have been reported elsewhere, including Malaysia, the Philippines, Indonesia, Venezuela, Guatemala (Rosales-Loessener et al., 1989; Kao, 1993), China (Anderson et al., 1996) and South Africa (Popkiss et al., 1979). PSP occurs in people who have eaten bivalve shellfish (i.e., clams, mussels, scallops, etc.) contaminated with one or more of a group of structurally related congeners of saxitoxin (Halstead and Shantz, 1984).

The PSP toxins are produced by dinoflagellates of the genera Gymnodinium (Anderson et al., 1989), Alexandrium (Anderson et al., 1996), and Pyrodinium (Halstead and Shantz, 1984). Saxitoxins are also produced by some species of freshwater cyanobacteria (Carmichael, 2001), but they have not been found to accumulate in freshwater shellfish. These toxins act selectively to block the voltage-gated sodium channel of excitable membranes, thus blocking the generation and propagation of action potentials in nerve axons and skeletal muscle fibers (Kao, 1993). Mammals, birds, and fish can be affected by PSP toxins; however, humans are the most sensitive- - the fatal oral dose of saxitoxin is 1-4 mg (Baden et al., 1995).

The onset of PSP symptoms usually occurs within 30 minutes to 3 hours. The initial symptoms of PSP are paresthesias and numbness around the lips and mouth (see Kao, 1993). These sensations then spread to the face and neck. Victims may also experience nausea and vomiting. In moderately severe poisonings, the
Figure 5. Photograph of two Alexandrium fundyense cells side by side. A. fundyense is a toxic dinoflagellate responsible for Paralytic Shellfish Poisoning. Image from D. Wall (ret.) provided courtesy of $D$. Anderson, Woods Hole Oceanographic Institution.

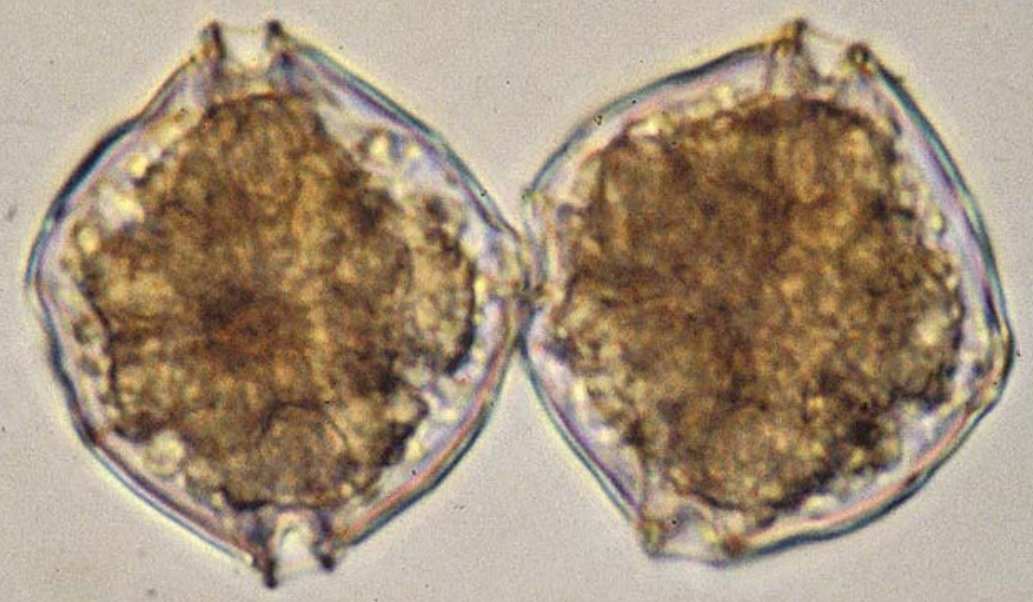

paresthesias progresses to the arms and legs. Victims may experience giddiness, incoherent speech, and light-headedness. In severe poisonings, death can result from respiratory failure and hypoxia. The fatality rate from PSP varies from no deaths in recent outbreaks in the United States or Europe to rates of 2-14 percent in other parts of the world (Kao, 1993). The frequency of mortality is primarily related to the availability of emergency hospital care, the effectiveness of monitoring programs, and past experience with PSP outbreaks as well as possibly the age of the victim.

The causative organism in New England PSP outbreaks is Alexandrium fundyense (Figure 5), whose complex life cycle includes a resting cyst, a phase of vegetative growth, sexual reproduction, and re-encystment (Figure 6, panel A). Observations in the Gulf of Maine indicate several salient characteristics of the vegetative cell distributions: patterns of abundance are gulf-wide in geographic scope; the distributions are associated with the Maine Coastal Current; and the center of mass of the distribution is from west to east during the April-to-August growing season (Townsend et al., 2001). This latter aspect is particularly notable given that the coastal current flows in the opposite direction (Figure 6, panel B). A model based on the seasonal mean flow that includes germination, growth, mortality, and nutrient limitation can produce simulations that are qualitatively consistent with the observations (Figure 6, panel C) (McGillicuddy et al., 2005). In general, cells germinated from the major cyst beds in the Bay of Fundy and near Penobscot and Casco Bays (Figure 6, panel D) are advected 
A

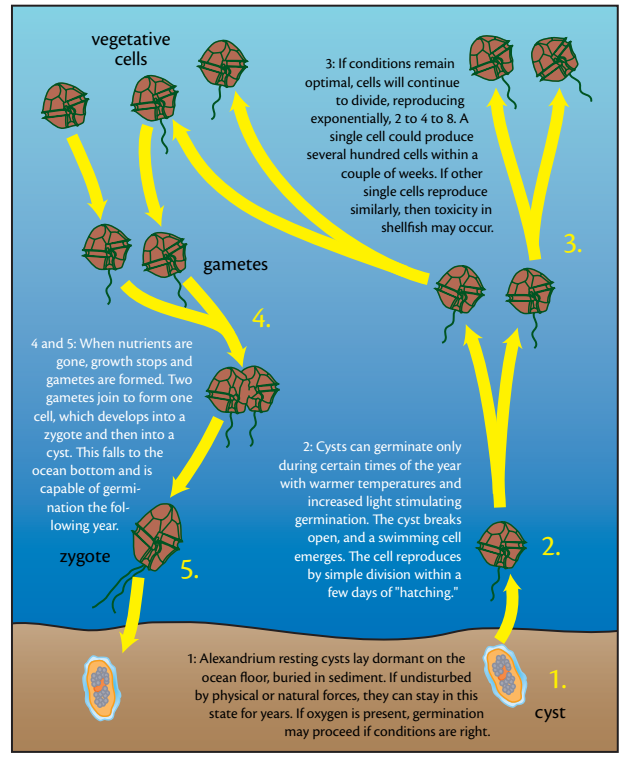

B

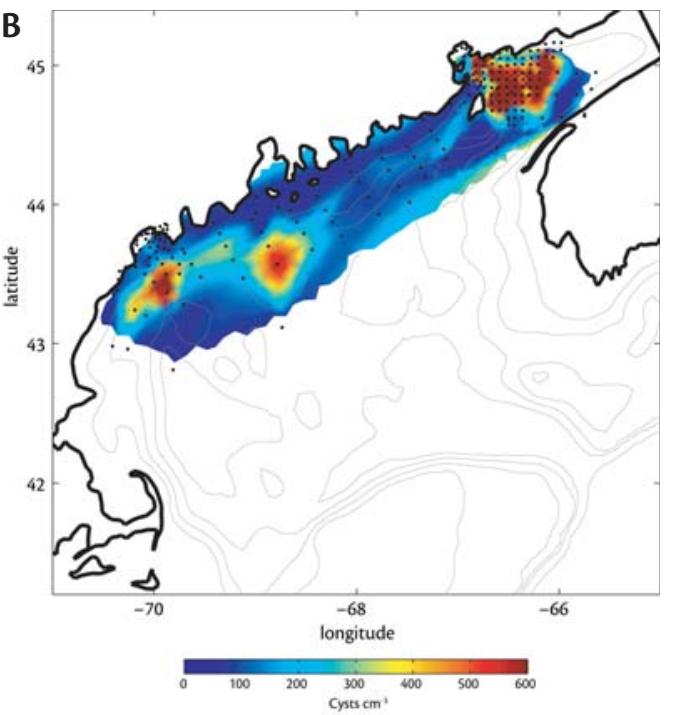

C

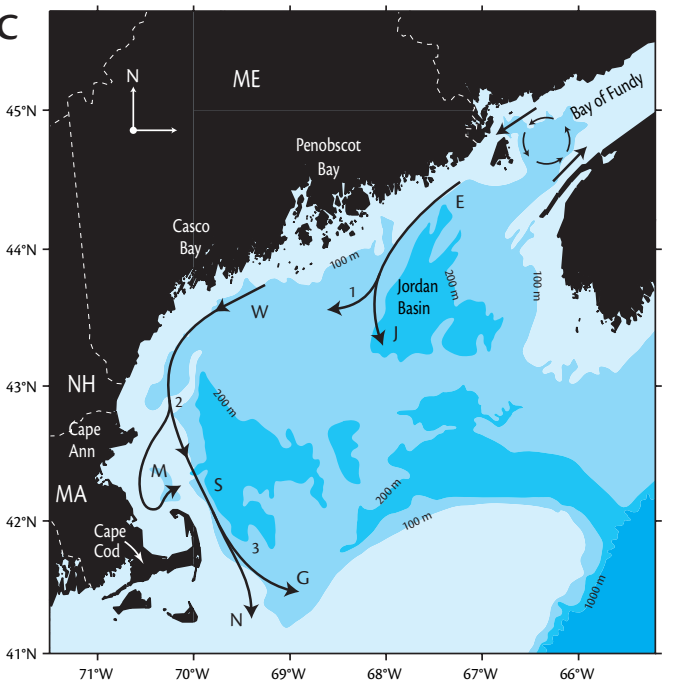

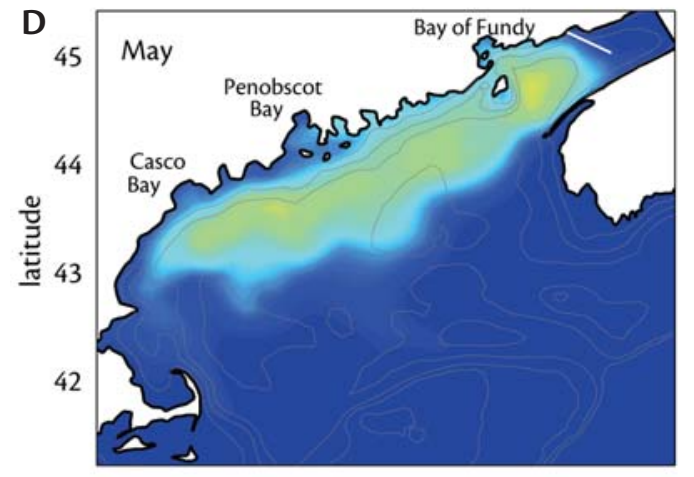
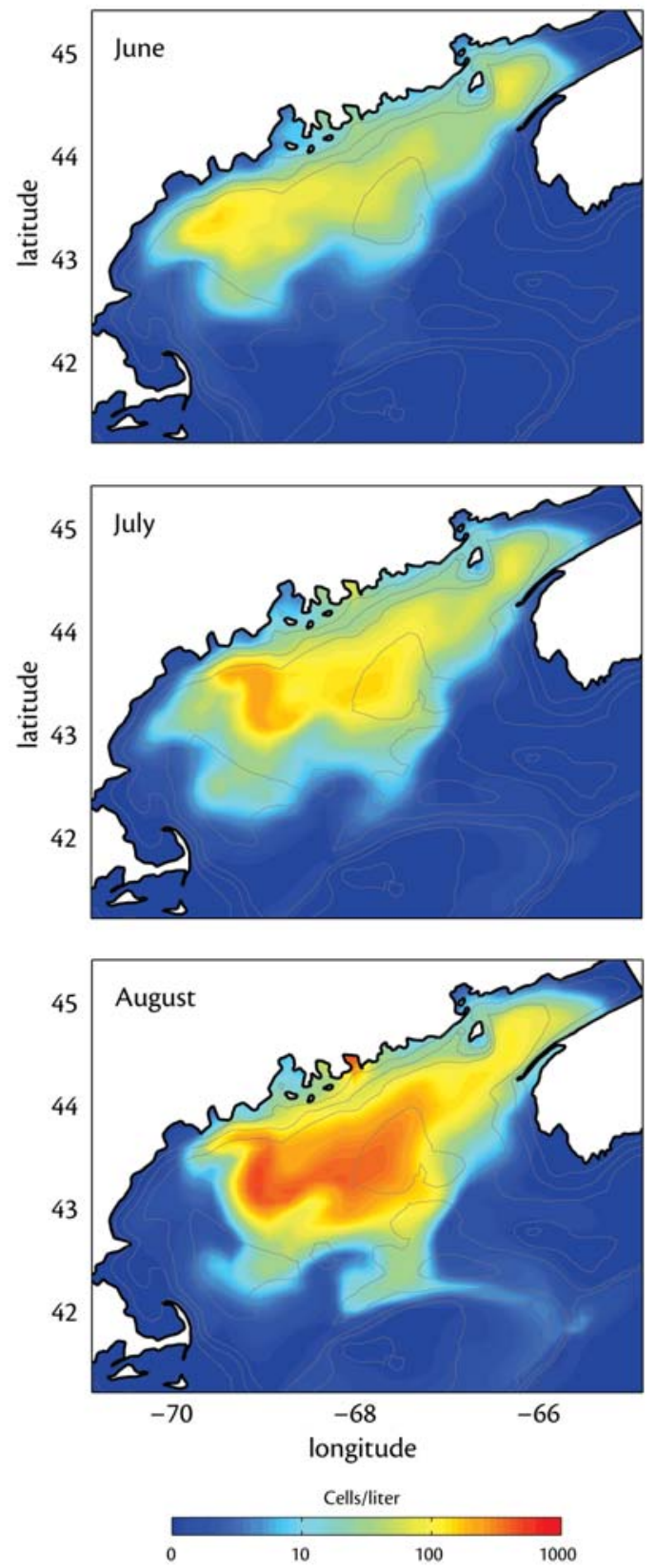

Figure 6. (A) Life cycle of $A$. fundyense. (B) Distribution of cysts (number of cysts $\mathrm{cm}^{-3}$ ) in the upper $1 \mathrm{~cm}$ of sediment derived from a 1997 survey of the Gulf of Maine (Anderson et al., 2005) and surveys of the Bay of Fundy in 1981 (White and Lewis, 1982), 1982 and 1983 (data provided by Jennifer Martin, Fisheries and Oceans Canada). (C) Schematic of the Maine Coastal Current, reprinted from McGillicuddy et al. (2005). Branch points are located at (1) Penobscot Bay, (2) Cape Ann, and (3) Great South Channel. Seven segments of the current are indicated: Eastern (E), Jordan (J), Western (W), Massachusetts (M), Stellwagen (S), Nantucket (N), and Georges Bank (G). Dashed white lines denote state boundaries of Maine (ME), New Hampshire (NH), and Massachusetts (MA). (D) Simulated A. fundyense distribution under climatological forcing conditions, illustrating three prominent aspects of the large-scale seasonal variations in these populations: (1) the vegetative cell distributions are gulf-wide in character, (2) peak cell concentrations occur in association with the Maine Coastal Current, and (3) the center of mass of the cell distribution shifts from west to east as the growing season progresses. 
down the coast from east to west in the coastal current. Growth of the vegetative cells is limited primarily by temperature from April through June throughout the gulf, whereas nutrient limitation occurs in July and August in the western gulf. Thus, the seasonal shift in the center of mass of cells from west to east can be explained by changing growth conditions: growth is more rapid in the western gulf early in the season because of warmer temperatures, whereas growth is more rapid in the eastern gulf later in the season because of severe nutrient limitation in the western gulf during that time period. Hydrodynamic transport of these offshore populations to inshore shellfish beds is a key aspect regulating the PSP threat to human health (Keafer et al., 2005; Luerssen et al., 2005).

\section{Ciguatera Fish Poisoning}

Ciguatera fish poisoning (CFP) out-

breaks typically occur within a circumglobal belt extending in latitude approximately from $35^{\circ} \mathrm{N}$ to $34^{\circ} \mathrm{S}$ (Hessel et al., 1960), and most reported U.S. cases occur in Hawaii, southern Florida, or after travel to the Caribbean (Glaziou and Legrand, 1994) or Pacific islands. The unicellular marine dinoflagellate, Gambierdiscus toxicus, found associated with coral reefs (Legrand et al., 1992), is the origin of gambiertoxins, a group of lipid-soluble polyether compounds. Gambiertoxins are passed through the coral reef food web where they are biotransformed into ciguatoxins that accumulate in large herbivorous and carnivorous fish (Lange, 1987). When caught, the fish appear to be healthy and have a normal taste and appearance. In addition, the toxicity of one fish does not predict the toxicity of other fish caught in the same geographic area.

CFP is clinically characterized by gastrointestinal effects (appearing a few hours after eating the fish) accompanied or followed by neurologic, and occasionally by cardiovascular, symptoms (e.g., bradycardia, hypotension) (Glaziou and Legrand, 1994). Sensory disturbances or paresthesias (such as numbness of the mouth and extremities and reversal of temperature sensation) and sometimes a generalized rash are distinctive features of CFP. The gastrointestinal symptoms usually persist for only a few days, whereas the neurologic symptoms may persist for up to several months (Blythe et al., 1994; Glaziou and Legrand, 1994; Quod and Turquet, 1995).

All the symptoms of CFP are reportedly more common in people suffering from a second or subsequent poisoning (Bagnis et al., 1979; Glaziou and Martin, 1993), and the symptoms may recur when victims eat fish or nuts or drink alcohol or caffeinated beverages (see Baden et al., 1995 for review). CFP is pleiomorphic with subjective symptoms and no easily available objective measures of health effects, making this disease one of the most challenging to diagnose (Pearn, 1994).

G. toxicus and other ciguatera-associated dinoflagellates generally occupy either benthic or epiphytic niches (Tindall and Morton, 1998). As such, they are not as strongly affected by the oceanographic processes that planktonic forms encounter. However, their growth rates depend on temperature and salinity, thus making their population dynamics sensitive to the ambient fluid environment. Hales et al. (1999) observed strong positive corre- lations between the annual incidence of CFP and local warming of the sea surface in a group of Pacific Islands that experienced heating during El Niño Southern Oscillation events. At another group of islands that experienced cooling of the sea surface during El Niño events, the opposite was observed. Several mechanisms were offered as explanations for this observed relationship between elevated temperatures and increased CFP incidence, including coral bleaching and disease.

As pointed out by Yasumoto et al. (1980), dead coral surfaces are rapidly colonized by filamentous or calcareous macroalgae, the preferred substrate of CFP-associated dinoflagellates. Physical disturbances of coral reefs (e.g., harbor construction) have also been associated with increased G. toxicus abundance (Lewis, 1986) and outbreaks of CFP (Ruff, 1989; de Sylva, 1994). Several other natural and anthropogenic influences can lead to degradation of the reef environment as well, including tourism, eutrophication, sewage and freshwater runoff, sedimentation due to erosion or dredging, and ship groundings (Lehane and Lewis, 2000). As a result, some have argued that CFP may be one of our most sensitive indicators of environmental disturbance in tropical marine ecosystems (Hales et al., 1999), although at present determining whether environmental degradation and change in tropical regions are affecting the incidence or severity of CFP is not possible.

\section{Cyanobacterial Toxin IIInesses}

In many areas of the world (e.g., Australia, United States), the HABs with potentially the greatest public health impact 
are cyanobacteria blooms in drinkingwater sources and recreational waters (both marine and freshwater) (see review by Backer, 2002). The primary toxinproducing cyanobacteria genera include: Anabena, Aphanizomenon, Cylindrospermopsis, Nodularia, Planktothrix (Oscillatoria), and Microcystis (Figure 7).

The neurotoxic cyanobacterial toxins include alkaloids (anatoxin-a and saxitoxins and neo-saxitoxin) and an organophosphate (anatoxin-a[s]) (Falconer, 1993). Anatoxin-a (from Anabena spp.) is a post-synaptic depolarizing neuromuscular blocker (Carmichael et al., 1990). Anatoxin-a(s) (also from Anabena spp.) is a potent anticholinesterase inhibitor similar in function to synthetic organophosphate insecticides. Saxitoxins (produced by some strains of Anabena and Aphanizomenon) are also produced by some marine dinoflagellates and can cause PSP.

The hepatotoxic cyanobacterial toxins are cyclic or ringed peptides (Carmichael and Falconer, 1993). Those with seven amino acids are microcystins (produced by some species and strains of Anabena, Microcystis, and Planktothrix). The peptides with five amino acids are nodularins (produced by Nodularin spumigena). These toxins inhibit specific protein phosphatase enzymes that are common to all eukaryotic cells (Falconer, 1993). Laboratory animal studies indicate that microcystins are tumor-promotors

(Nishiwaki-Matshushima et al., 1992) and teratogens (Falconer et al., 1988) as well as acute hepatotoxins. An additional hepatotoxin, cylindrospermopsin, has been isolated from Cylindrospermopsis raciborskii (Hawkins et al., 1997). Cylindrospermopsin is a potent protein syn-

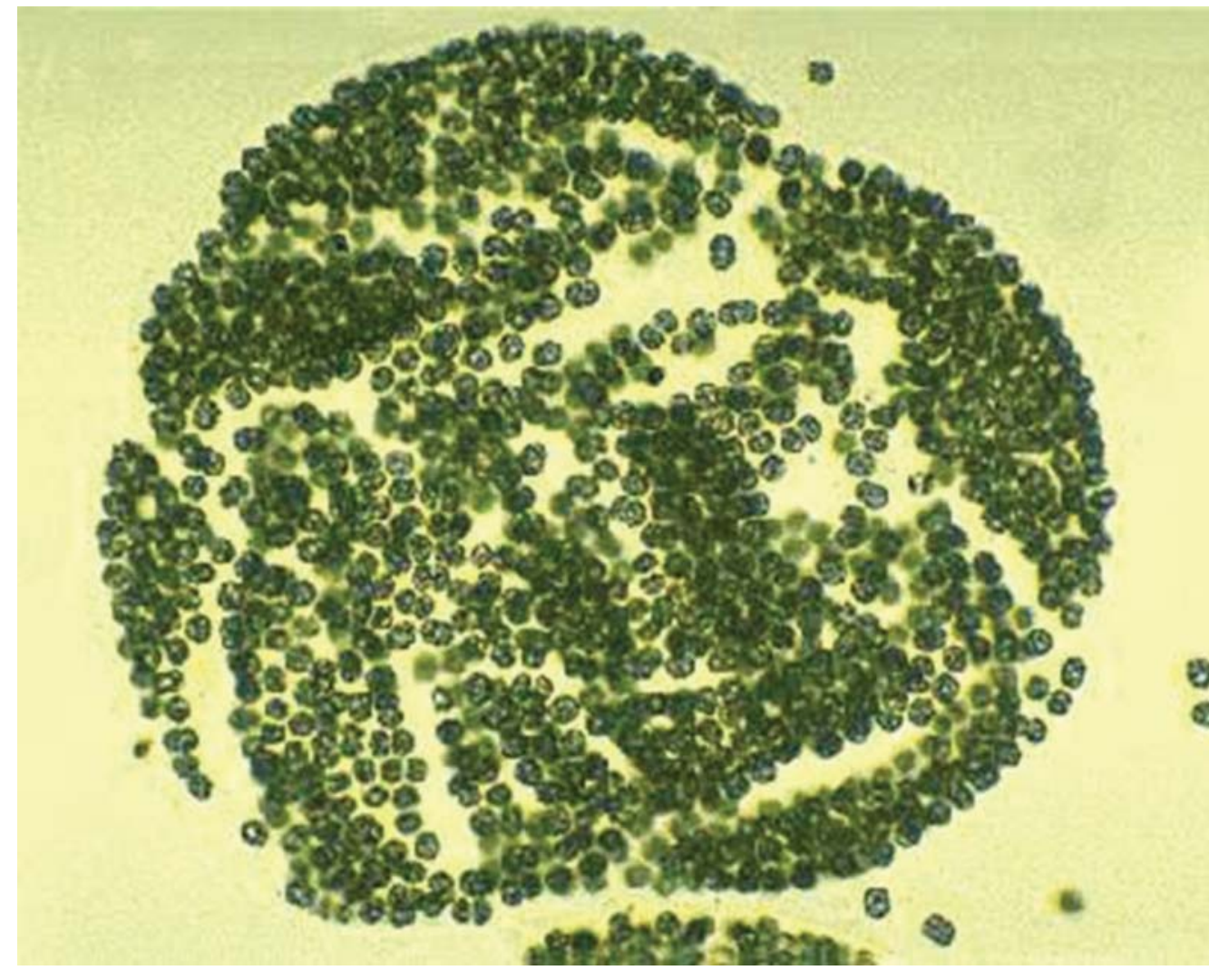

Figure 7. Microcystis sp., a cyanobacterium that can reach extraordinary concentrations during bloom conditions (Figure 8). Image courtesy of Isao Inouye (University of Tsukuba), Mark Schneegurt (Wichita State University), and Cyanosite (www-cyanosite.bio.purdue.edu).

thesis inhibitor and causes chromosome breakage and loss in vitro (Humpage et al., 2000).

Animals are more frequently and more seriously poisoned than humans because animals are more likely to drink or swim in water that humans avoid because of foul taste or smell (Senior, 1960). Also, dogs have died from nodularin or anatoxin-a poisoning after licking blue-green scum from their coats (Codd et al., 1992).

Humans may be exposed to cyanobacterial toxins through drinking water and aquatic recreation (Carmichael and Fal- coner, 1993), either by direct contact or accidental uptake by swallowing water or inhaling aerosols during recreational and occupational activities. The use of untreated water sources for irrigation and lawn watering may put humans at risk for exposure through aerosols containing cells or toxins. The Florida Department of Health reported both respiratory (e.g., irritation and shortness of breath) and dermatologic (e.g., itchy skin, rashes) symptoms in people occupationally exposed to an extensive bloom of Microcystis aeruginosa on the St. Johns River during the summer of 2005 (Andrew Reich, 
Florida Department of Health, personal communication, September 2005).

Extraordinary blooms of Microcystis have taken place in the Great Lakes recently (Figure 8). In August 2003, a massive bloom of the cyanobacterium $M$. aeruginosa formed in western Lake Erie, and persisted for nearly a month. Surface scums of Microcystis containing high concentrations of the toxin microcystin washed ashore in Michigan and Ohio, resulting in foul-smelling, rotting algal mats. Beaches and recreational boating areas were rendered unusable, and sport fishing was adversely affected. The Microcystis bloom of 2003 was perhaps the most severe in Lake Erie's recent history, but it was only the latest in a trend towards increasing frequency of Microcystis blooms in the last decade (Bridgeman, 2005; see http://www. lakeerie.utoledo.edu/html/tomres1. $\mathrm{htm})$. Understanding the dynamics of these blooms is a focus of the National Oceanic and Atmospheric Administration (NOAA) Center of Excellence for Great Lakes and Human Health (http:// www.glerl.noaa.gov/res/Centers/ HumanHealth). Given the clear evidence for substantial transport of these blooms via coastal currents, numerical models are being developed in which cyanobacterial dynamics are coupled to hydrodynamics with the aim of eventually transitioning such models to ecological forecasting applications.
Figure 8. Microcystis bloom August 2003. Below: Landsat 7 photo of western Lake Erie provided by OhioView/T. Bridgeman. Right: Microcystis "shake" from a surface sample, photo courtesy of T. Bridgeman.

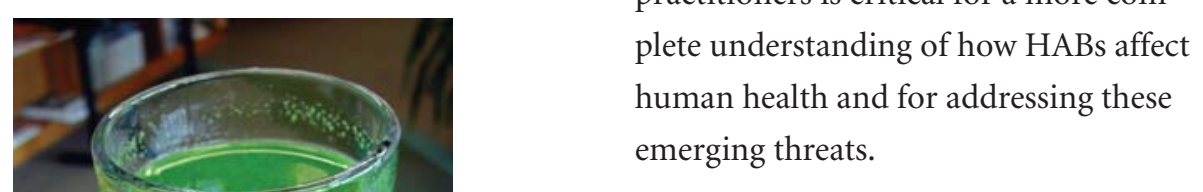

\section{ACKNOWLEDGEMENTS}

We are grateful for the input of the following individuals who contributed to this article: Don Anderson, Deana Erdner, Barbara Hickey, Vera Trainer, Rick Stumpf, and Steve Brandt. DJM was supported by the Woods Hole Center for Oceans and Human Health, sponsored by the National Science Foundation and the National Institute of Environmental Health Sciences. 四

\section{REFERENCES}

Anderson, D.A., J. Sullivan, and B. Reguera. 1989. Paralytic shellfish poisoning in northwest Spain: The toxicity of the dinoflagellate Gymnodinium catenatum. Toxicon 27:665-674.

Anderson, D.A., D. Kulis, Y.-Z. Qi, L. Zheng, S. Lu, and Y.-T. Lin. 1996. Paralytic shellfish poisoning in southern China. Toxicon 34:579-590. 
Anderson, D.M., C, Stock, B. Keafer, A. Bronzino, D. McGillicuddy, M. Keller, B. Thompson, P. Matrai, and J. Martin. 2005. Experimental observations and modeling of Alexandrium fundyense cyst dynamics in the Gulf of Maine. Deep Sea Research II 52(19-21):2,522-2,542.

Aune, T., and M. Yndestad. 1993. Diarrhetic shellfish poisoning. Pp. 87-104 in Algal Toxins in Seafood and Drinking Water, I.R. Falconer, ed. Academic Press, London.

Backer, L.C. 2002. Cyanobacterial harmful algal blooms (CyanoHABs): Developing a public health response. Lake and Reservoir Management 18(1):20-31.

Backer, L.C., L. Fleming, A. Rowan, and D. Baden. 2003. Epidemiology and public health of human illnesses associated with harmful marine algae. Pp. 723-749 in Manual on Harmful Marine Microalgae, G.M. Hallegraeff, D.M. Anderson, and A.D. Cembella, eds. UNSECO Publishing, Paris.

Backer, L.C., B. Kirkpatrick, L. Fleming, Y.-S. Cheng, R. Pierce, J. Bean, R. Clark, D. Johnson, A. Wanner, R. Tamer, and D. Baden. 2005a. Occupational Exposure to Aerosolized Brevetoxins during Florida Red Tide Events: Impacts on a Healthy Worker Population. Environmental Health Perspectives 113-115:644-649.

Backer, L.C., H. Rogers, L. Fleming, B. Kirkpatrick, and J. Benson. 2005b. Phycotoxins in marine seafood. Pp. 155-189 in Toxins in Food, W.M. Dabrowski and Z.E. Sikorski, eds, CRC Press, Boca Raton, FL.

Baden, D.G. 1983. Marine food-borne dinoflagellate toxins. International Review of Cytology 82:99-150.

Baden, D.G. 1989. Brevetoxins: Unique polyether dinoflagellate toxins. Federation of American Societies for Experimental Biology Journal $3: 1,807-1,817$.

Baden, D., L. Fleming, and J. Bean. 1995. Marine Toxins. Pp. 141-175 in Handbook of Clinical Neurology: Intoxications of the Nervous System Part II. Natural Toxins and Drugs, F.A. deWolff, ed. Elsevier Press, Amsterdam, The Netherlands.

Bagnis, R., T. Kuberski, and S. Laugeir. 1979. Clinical observations on 3,009 cases of ciguatera (fish poisoning) in the South Pacific. American Journal of Tropical Medicine and Hygiene 28:1,067-1,073.

Blythe, D., L. Fleming, D. Ayyar, D. Baden, D. De Sylva, and K. Shrank. 1994. Mannitol treatment for acute and chronic ciguatera fish poisoning. Memoirs Queensland Museum 34: 65-470.

Bridgeman, T.B. 2005. Paper presented at the $48^{\text {th }}$ Annual Meeting of the International Association for Great Lakes Research, Ann Arbor, Michigan, May 23-27, 2005.

Carmichael, W.W. 2001. Health effects of tox- in-producing cyanobacteria: "The CyanoHABs." Human and Ecological Risk Assessment 7(5):1,393-1,407.

Carmichael, W.W., and I. Falconer. 1993. Diseases related to freshwater blue-green algal toxins, and control measures. Pp. 187-209 in Algal Toxins in Seafood and Drinking Water, I.R. Falconer, ed., Academic Press, London.

Carmichael, W.W., N. Mahmood, and E. Hyde. 1990. Natural toxins from cyanobacteria (bluegreen algae). Pp. 87-106 in Marine Toxins; Origin, Structure and Molecular Pharmacology, ACS Symposium Series 418, S. Hall and G. Strichartz, eds. American Chemical Society, Washington, D.C.

Daugbjerg, D., G. Hansen, J. Larsen, and Ø. Moestrup. 2000. Phylogeny of some of the major genera of dinoflagellates based on ultrastructure and partial LSU rDNA sequence data, including the erection of three new genera of unarmoured dinoflagellates. Phycologia 39:302-317.

de Sylva, D.P. 1994. Distribution and ecology of ciguatera fish poisoning in Florida, with emphasis on the Florida Keys. Bulletin of Marine Science 54(3):944-954.

Falconer, I. 1993. Measurement of toxins from blue-green algae in water and foodstuffs. Pp. 165-175 in Algal Toxins in Seafood and Drinking Water, I.R. Falconer, ed. Academic Press, London.

Falconer, I.R., J.V. Smith, A.R.B. Jackson, A. Jones, and M.T. Runnegar. 1988. Oral toxicity of a bloom of the cyanobacterium Microcystis aeruginosa administered to mice over periods of up to one year. Journal of Toxicology and Environmental Health 24:291-305.

Fleming, L.E., L. Backer, and A. Rowan. 2002. The Epidemiology of Human Illnesses Associated with Harmful Algal Blooms. Pp. 363-381 in Neurotoxicology Handbook, Volume 1: Natural Toxins of Marine Origin, D.J. Adams, D. Baden, J. Bloomquist, M. Ehrich, T. Guilarte, A. Harvey, eds. Humana Press, Totowa, NJ.

Fleming, L.E., B. Kirkpatrick, L. Backer, J. Bean, A. Wanner, D. Dalpra, R. Tamer, J. Zaias, Y.-S. Cheng, R. Pierce, J. Naar, W. Abraham, R. Clark, Y. Zhou, M. Henry, D. Johnson, G. Van de Bogart, G. Bossart, M. Harrington, and D. Baden. 2005. Initial Evaluation of the Effects of Aerosolized Florida Red Tide Toxins (Brevetoxins) in Persons with Asthma. Environmental Health Perspectives 113-115:650-657.

Franks, P.J.S. 1997. Spatial patterns in dense algal blooms. Limnology and Oceanography 42:1,2971,305 .

Gentien, P., P. Donaghay, H. Yamazaki, R. Raine, B. Reguera, and T. Osborn. 2005. Harmful algal blooms in stratified environments. Oceanography 18(2):172-183.
Glaizou, P., and P.V. Martin. 1993. Study of factors that influence the clinical response to ciguatera fish poisoning. Toxicon 31:1,151-1,154.

Glaziou, P., and A.-M. Legrand. 1994. The epidemiology of ciguatera fish poisoning. Toxicon 32:863-873.

Glibert, P.M., D. Anderson, P. Gentien, E. Granéli, and K. Sellner. 2005. The global, complex phenomena of harmful algal blooms. Oceanography 18(2):136-147.

Hales, S., P. Weinstein, and A. Woodward. 1999. Ciguatera (fish poisoning), El Niño, and $\mathrm{Pa}-$ cific sea surface temperatures. Ecosystem Health 5(1):20-25.

Halstead, B.W., and E. Shantz. 1984. Paralytic shellfish poisoning. WHO Offset Publication No. 79. World Health Organization, Geneva, Switzerland, $59 \mathrm{pp}$.

Hawkins, P.R., N. Chandrasena, G. Jones, A. Humpage, and I. Falconer. 1997. Isolation and toxicity of Cylindrospermopsis raceborskii from an ornamental lake. Toxicon 35:341-346.

Hessel, D.W., B. Halstead, and N. Peckham. 1960. Marine biotoxins. 1. Ciguatera poisoning some biological and chemical aspects. Annals of the New York Academy of Sciences 90:788-797.

Hughes, J.M., and M. Merson. 1976. Fish and shellfish poisoning. New England Journal of Medicine 295:1,117-1,120.

Humpage, A.R., M. Fenech, P. Thomas, and I. Falconer. 2000. Micronucleus induction and chromosome loss in transformed human white cells indicate clastogenic and aneugenic action of the cyanobacterial toxin, cylindrosperopsin. Mutation Research/Genetic Toxicology Environmental Mutagenesis 472(1-2):155-161.

Ishida, H., N. Muramatsu, T. Kosuge, and K. Tsuji. 1996. Study on neurotoxic shellfish poisoning involving New Zealand shellfish, Crassostrea gigas. Pp. 491-494 in Harmful and Toxic Algal Blooms, T. Yasumoto, Y. Oshima, and Y. Fukuyo, eds. Intergovernmental Oceanographic Commission (UNESCO), Paris, France.

Kao, C.Y. 1993. Paralytic shellfish poisoning. Pp. 75-86 in Algal Toxins in Seafood and Drinking Water, I.R. Falconer, ed. Academic Press, London.

Kat, M. 1979. The occurrence of Prorocentrum species and coincidental gastrointestinal illness of mussel consumers. Pp. 215-220 in Toxic Dinoflagellate Blooms, D. Taylor and H.H. Seliger, eds, Elsevier North-Holland, Amsterdam, The Netherlands.

Keafer, B.A., J.H. Churchill, D.J. McGillicuddy, and D.M. Anderson. 2005. Bloom development and transport of toxic Alexandrium fundyense populations within a nearshore coastal plume in the Gulf of Maine. Deep Sea Research II 52:2,674-2,697. 
Lange, W.R. 1987. Ciguatera toxicity. American Family Physician Journal 35:177-182.

Legrand, A.M., M. Fukui, P. Cruchet, Y. Ishibashi, and T. Yasumoto. 1992. Characterization of ciguatoxins from different fish species and Gambierdiscus toxicus. Pp. 25-32 in Toxic Marine Phytoplankton, E. Granéli, B. Sundström,

L. Edler, and D.M. Anderson, eds. Elsevier, New York, NY.

Lehane, L., and R. Lewis. 2000. Ciguatera: Recent advances but the risk remains. International Journal Food Microbiology 61:91-125.

Lewis, N.D. 1986. Disease and development: Ciguatera fish poisoning. Social Science and Medicine 23:983-993.

Luerssen, R.M, A.C. Thomas, and J. Hurst. 2005. Relationships between satellite-measured thermal features and Alexandrium-imposed toxicity in the Gulf of Maine. Deep Sea Research II 52(19-21):2,656-2,673.

MacFadyen, A., B. Hickey, and M.G.G. Foreman. 2005. Transport of surface waters from the Juan de Fuca eddy region to the Washington coast. Continental Shelf Research 25(16):2,008-2,021.

MacFadyen, A., B. Hickey, W. Cochlan, and V. Trainer. In preparation. Variability in summertime circulation and water properties (including macronutrients, chlorophyll and domoic acid) on the Washington/British Columbia coast, 2003-2005. Journal of Geophysical Research.

McFarren, E.F., H. Tanabe, F. Silva, W. Wilson, J. Campbell, and K. Lewis. 1965. The occurrence of a ciguatera-like poison in oysters, clams and Gymnodinium cultures. Toxicon 3:111-123.

McGillicuddy, D.J., D. Anderson, D. Lynch, and D. Townsend. 2005. Mechanisms regulating the large-scale seasonal fluctuations in Alexandrium fundyense populations in the Gulf of Maine: Results from a physical-biological model. Deep Sea Research II 52:2,698-2,714.

Music, S.J, J.T. Howell, and C.L. Brumback. 1973. Red tide its public health implications. Journal of the Florida Medical Association 60:27-29.

Nishiwaki-Matsushima, R., T. Ohta, S. Nishiwaki, M. Suganuma, K. Kohyama, T. Ishikawa, W.W. Carmichael, and H. Fujiki. 1992. Liver cancer promotion by the cyanobacterial cyclic peptide toxin microcystin-LR. Journal of Cancer Research and Clinical Oncology 118:420-424.

Pearn, J. 1994. Ciguatera: Dilemmas in clinical recognition, presentation and management. Memoirs Queensland Museum 34:601-604.

Perl, T.M., L. Bedard, T. Kosatsky, J.C. Hockin, E.C.D. Todd, and R.S. Remis. 1990. An outbreak of toxic encephalopathy caused by eating mussels contaminated with domoic acid. New England Journal of Medicine 322:1,775-1,780.

Popkiss, M.E.E., D. Horstman, and D. Harpur. 1979. Paralytic shellfish poisoning. South Africa
Medical Journal 55:1,017-1,023.

Prakash, A., J. Medcof, and A. Tennant. 1971. Paralytic shellfish poisoning in eastern Canada. Bulletin 177. Fisheries Research Board of Canada, Ottawa, 87 pp.

Quod, J.P., and J. Turquet. 1995. Ciguatera in Réunion Island (SW Indian Ocean): Epidemiology and clinical patterns. Toxicon 34:779-785.

Reguera, B., I. Bravo, and S. Fraga. 1995. Autoecology and Some Life-History Stages of DinophysisAcuta Ehrenberg. Journal of Plankton Research 17(5):999-1,015.

Rosales-Loessener, F., E. De Porras, and M.W. Dix. 1989. Toxic shellfish poisoning in Guatemala. Pp. 113-116 in Red Tides: Biology, Environmental Science, and Toxicology, T. Okaichi, D.M. Anderson, and T. Nemoto, eds. Elsevier, New York, NY.

Ruff, T.A. 1989. Ciguatera in the Pacific: A link with military activities. Lancet 1:201-204.

Sakamoto, Y., R. Lockey, and J. Krzanowski. 1987. Shellfish and fish poisoning related to the toxic dinoflagellates. Southern Medical Journal 80:866-872.

Schulman, L.S., L.E. Roszell, T.J. Mende, R.W. King, and D.G. Baden. 1990. A new polyether toxin from Florida's red tide dinoflagellate Ptychodiscus brevis. Pp. 407-412 in Toxic Marine Phytoplankton., E. Granéli, B. Sundström, L. Edler, D.M. Anderson, eds. Elsevier, New York, NY.

Senior, V.E. 1960. Algal poisoning in Saskatchewan. Canadian Journal of Comparative Medicine 24:26-40.

Smayda, T.J., and C. Reynolds. 2001. Community assembly in marine phytoplankton: Application of recent models to harmful dinoflagellate blooms. Journal of Plankton Research 23(5):447461.

Steidinger, K. 1993. Toxic dinoflagellates. Pp. 1-28 in Algal Toxins in Seafood and Drinking Water, I.R. Falconer, ed, Academic Press, London.

Steidinger, K.A., and K. Haddad. 1981. Biologic and hydrographic aspects of red tides. Bioscience 31(11):814-819.

Stumpf, R.P., M.E. Culver, P.A. Tester, M. Tomlinson, G.J. Kirkpatrick, B.A. Pederson, E. Truby, V. Ransibrahmanakul, and M. Soracco. 2003. Monitoring Karenia brevis blooms in the Gulf of Mexico using satellite ocean color imagery and other data. Harmful Algae 2(2):147-160.

Tindall, D.R., and S. Morton. 1998. Community dynamics and physiology of epiphytic/benthic dinoflagellates associated with ciguatera. Pp. 293-313 in Physiological Ecology of Harmful Algal Blooms, D.M. Anderson, A.D. Cembella, and G.M. Hallegraeff, eds. Springer-Verlag, Berlin, Germany.

Townsend, D.W., N. Pettigrew, and A. Thomas. 2001. Offshore blooms of the red tide dinoflagellate Alexandrium spp., in the Gulf of Maine.
Continental Shelf Research 21:347-369.

Trainer, V.L., and M. Suddleson. 2005. Monitoring approaches for early warning of domoic acid events in Washington State. Oceanography 18(2):228-237.

Trainer, V.L., B. Hickey, and R.A. Horner. 2002. Biological and physical dynamics of domoic acid production off the Washington coast. Limnology and Oceanography 47(5):1,438-1,446.

Walsh, J.J., and K. Steidinger. 2001. Saharan dust and Florida red tides: The cyanophyte connection. Journal of Geophysical Research-Oceans 106(C6):11,597-11,612.

Walsh, J.J., R. Weisberg, D.A. Dieterle, R. He, B.P. Darrow, J.K. Jolliff, K.M. Lester, G.A. Vargo, G.J. Kirkpatrick, K.A. Fanning, T.T. Sutton, A.E. Jochens, D.C. Biggs, B. Nababan, C. Hu, and F.E. Muller-Karger. 2003. Phytoplankton response to intrusions of slope water on the West Florida Shelf: Models and observations. Journal of Geophysical Research-Oceans 108(C6):3190, doi:10.1029/2002JC001406.

White, A.W., and C. Lewis. 1982. Resting cysts of the toxic red tide dinoflagellate Gonyaulax excavata in Bay of Fundy sediments. Canadian Journal of Fisheries and Aquatic Sciences 39:1,185-1,194.

Yasumoto, T., Y. Oshima, and M. Yamaguchi. 1978. Occurrence of a new type shellfish poisoning in the Tohoku district. Bulletin of the Japanese Society of Scientific Fisheries 46:1,405-1,411.

Yasumoto, T., A. Inoue, T. Ochi, K. Fujimuto, Y. Oshima, Y. Fukuyo, R. Adachi, and R. Bagnis. 1980. Environmental studies on a toxic dinoflagellate responsible for ciguatera. Bulletin of the Japanese Society of Scientific Fisheries/Nissuishi 46:1,397-1,404. 